\title{
Evaluasi Kebutuhan Udara Ventilasi Untuk Kamar Mesin Karena Penggantian Rpm Motor Penggerak Axial Fanpada Kapal Perintis 2000GTBerpenggerak Mesin Induk (Main Engine) 2 x $1400 H P$
}

\author{
Ratna Dwi Kurniawan \\ ${ }^{1 *}$ Program Studi T.Bangunan Kapal, Fakultas Kemaritiman, Universitas Ivet \\ *Email : rtnkurniawan@gmail.com
}

\begin{abstract}
ABSTRAK
Sistem ventilasi udara untuk kamar mesin (engine room) memegang peranan sangat pentinng sekali, sebagai suplai udara pembakaran mesin dan mendinginkan udara di ruang kamar mesin. Jika suplai bahan bakar kekurangan udara/oksigen (O2) berpengaruh pada power yang dihasilkan, sehingga effisiensi turun. Latar belakang penulisan karena adanya penggantian putaranmotor fan/blower penyuplai udara ventilasi untuk main engine, sehingga perlu di lakukan perhitungan ulang untuk mendapatkan kebutuhan udara yang sesuai dengan kebutuhan. Metode ASHRAE dan ISO 8861 telah digunakan peneliti lain pada kapal sejenis di lain galangan. Sebagai bahan pembanding, metode yang digunakan dalam penelitian ini adalah penggunaan user guide dari marine engineering department yang lebih sederhana.Dari hasil evaluasi diketahuikebutuhan untuk udara pembakaran main engine 5259,39 $\mathrm{m}^{3} / \mathrm{h}$ paling kecil diantara metode lain, tetapi total kapassitas udara untuk pembakaran main engine dan difusi panas, berada diantara metode ASHARE dan ISO 8861, yaitu sebesar 23.053,37cfm sedangkapasitas fan yang tepasang 30000cfm,
\end{abstract}

Kata kunci: “ventilasi”, “engine room”, ,kamar mesin”, ” axial fan"

\section{PENDAHULUAN}

Untuk mendukung program Tol laut, pemerintah RI, melalui departemen perhubungan telah memesan 100 kapal yang terdiri dari berbagai tipe seperti kapal perintis, kapal ternak, kapal kontainer dan kapal rede.Kapal-kapal tesebut diharapkan dapat menjadi koneksi antar pulau di seluruh indonesia, meningkatkan perputaran ekonomi secara nasional, menghilangkan disparitas, memperkokoh persatuan dan kesatuan bangsa indonesia. (www.republika.co.id /berita/ekonomi).

Kapal-kapal perintis tersebut terdiri dari berbagai tipe/jenis, ukuran dan kapasitas diantaranya kapal perintis sabuk nusantara 2000GT dan 1200GT, dimana 2000GT memiliki panjang 68,5meter, kapasitas penumpang 466 orang dan ruang muat 150 ton. Sedang 1200GT memiliki panjang $62,8 \mathrm{~m}$ dengan kasitas penumpang 400 orang dan ruang muat 50 ton. Tipe kedua adalah kapal kontainer 100 teus yang memliki panjang 74,5meter dengan kapasitas angkut 100TEUs kontainer. Berikutnya kapal ternak dengan panjang 69,78 meter dan mampu mengangkut 500 ekor ternak dan memiliki kapasitas ruang muat 150 ton.

Dari beberapa kapal perintis tersebut, kapal 2000GT merupakan kapal terbesar dengan kapasitas 2000 Gross Tonage dengan panjang 68,5 meters, tinggi 6,2meter dan lebar 14meter. Kapal 2000GT memiliki dua motor penggerak (main engine) masingmasing berdaya 1400 tenaga kuda, mampu berlayar sejauh 3500mil laut dengan kecepatan 12Knot.

GT2000 termasuk tipe kapal penumpang (passenger), karena memiliki penumpang lebih dari 12 orang selain crew (SOLAS). Kapal penumpang termasuk kapal yg memiliki persyaratan kelaiklautan, keselamatan yang tinggi, di Indonesia badan yang berwenang mengurusi kelayakan secara teknis adalah Biro Klasifikasi Indonesia (BKI). BKI Mengawasi dan mengeluarkan approval sejak perencanaan kapal, proses pembuatan hingga saat kapal beroperasi.

Persyaratan teknis meliputi konstruksi kapal, sistem permesinan, kelistrikan, keselamatan dll semua harus melalui persetujuan BKI. Salah satu persyaratan 
yang berhubungan dengan ruang kamar mesin di kapal yang harus di penuhi adalah temperatur ruang yang tidak boleh melebihi $45^{\circ}$ (BKI Rule, vol III, section 1). Hal tersebut untuk menjaga peralatan tetap bekerja secara optimal serta crew yang berada di kamar mesin juga bekerja dengan nyaman.

Temperatur didalam kamar mesin dapat diturunkan dengan cara mengalirkan udara ventilasi dari main deck/ruang terbuka dengan bantuan blower/fan. Udara ventilasi di kamar mesin tidak hanya untuk mendinginkan temperatur saja, tapi lebih dari itu untuk memenuhi kebutuhan udara pembakaran $\left(\mathrm{O}_{2}\right)$ untuk main engine/mesin penggerak utama, generator set/auxiliary engine dan boiler. Kebutuhan udara pembakaran harus dihitung terlebih dahulu sebelum menentukan jenis dan kapasitas blower yang terpasang sampai kurang.

Latar belakang penulisan artikel ini adalah adanya penggantian motor listrik sebagai penggerak fan/bloweruntuk udara ventilasi di kamar mesin, dengan spesifikasi 960 Rpm, lebih tinggi dari spesifikasi awal, namun lebih rendah dari penggantian motor listrik pertamakali dengan putara diatas 1000 Rpm, dengan putaran diatas $1000 \mathrm{Rpm}$ terjadi suara yang sangat berisik dan dikawatirkan merusak fan blade sehingga diambil keputusan putaran diturunkan lagi namun masih diatas daris spesifikasi awal. Dasar penggantian adalah kasaitas peralatan yang dinilai kecil/kapasitas tidak mencukupi. Awalnya fihak galangan berencana melakukan penggantian satu unit/sets blower, namun karena tempatnya/letaknya terbatas fan bladetidak dapat diganti dengan diameter yang lebih besar untuk mendapatkan debit aliran udara yang lebih besar. Karena keterbatasan tersebut, keputusan akhirnya hanya dilakukan dengan penggantian motor blower dengan putaran per menit (RPM) lebih tinggi, tanpa merubah diameter fan.

Artikel ini ditulis dengan maksud dan tujuan menghitung dan mengetahui kapasitas udara ventilasi untuk kamar mesin sebelum diadakan penggantian, seberapa besar pengaruh perubahan kapasitas udara dari fan/blower karena peningkatan RPM tanpa merubah blade denganmenghitung jumlah udara yang harus di suplai ke dalam kamar mesin dengan adanya 2 x 1400HP mesin induk dan 3 generators setserta 1 generator pelabuhan dengan menggunakan beberapa metode perhitungansehingga dapat diketahi data pembanding sebagai dasar pengambilan keputusan yang terbaik.

Sebagai batasan masalah dalam penulisan artikel ini adalah hanya membahas permasalahan di salah satu kapal sabuk nusantara 2000GT yang di produksi di salah satu perusahaan kapal di Semarang. Sistem ventilasi juga dibatasi pada kebutuhan di kamar mesin, tidak sampai dengan ruang penumpang/barang.

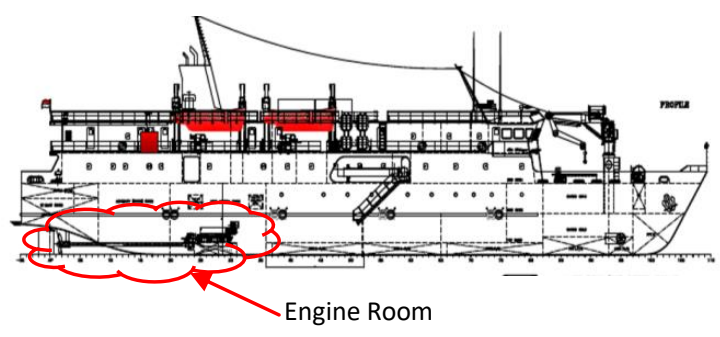

Gambar 1. Letak kamar mesin kapal perintis 2000GT

Manfaat dari karya tulis ini diharapkan dapat digunakan sebagai bahan pertimbangan dalam perencanaan kamar mesin khususnya kebutuhan udara ventilasi, tataletak mesin dan komponen pendukung lainnya.

\section{TINJAUAN PUSTAKA}

Kamar mesin (Engine room) merupakan salah satu ruangan terpenting di dalam sebuah kapal, dikarenakan di dalam ruang kamar mesin inilah diletakkan main engine sebagai mesin penggerak utama kapal, generator set/pembangkit tenaga listrik, boiler, motor-motor listrik, pompa, penukar kalor/heat exchanger, tangki bahan bakar, main switch board dan permesinan lainnya. 
Kamar mesin di kapal adalah ruangan tertutup dan didalam kapal (biasanya posisinya dibagian bawah dan di belakang lihat gambar 2.) dan memiliki volume yang terbatas hal ini dikarenakan tujuan utama kapal adalah dapat mengangkut muatan sebanyak-banyaknya jadi diusahakan dalam perencanaan kamar mesin dibuat seminimal mungkin, sebaliknya ruang muat dibuat sebesar mungkin. Dalam keterbatasan volume kamar mesin perencanaan kamar mesin dituntut harus sesuai dengan peraturan yang berlaku seperti tataletak permesinan, tinggi platform, jarak antara permesinan dan tanki sampai dengan temperatur dalam kamar.

Dengan lokasi kamar mesin yang tertutup dan terbatas maka dibutuhan udara ventilasi.Ventilasi sangat penting, karena sebagai penyedia udara pembakaran bahan bakar dan sebagai sarana untuk mendinginkan temperatur sesuai ketentuan rule digunakan. Kekurangan udara pembakaran $\left(\mathrm{O}_{2}\right)$ akan menyebabkan tenaga/power engine turun yang berarti effisiensinya menjadi rendah. Karena untuk mencapai power level yang telah ditentukan, mesin induk dan genset harus membakar bahan bakar yang lebih banyak.

Udara yang panas akibat emisi dari motor bakar dan permesinan lainnya, tidak hanya mempengaruhi kinerja mesin, tetapi juga akan mempengaruhi laju kegagalan/ kerusakan mesin, peralatan yang ada di engine room, seperti compressor, generator dan sistem/peralatan kelistrikan. Sehingga dapat disimpulkan fungsi dari ventilasi ruang kamar mesin adalah:

1) Menjaga peralatan di engine roomtetap bersih dan bekerja sebagaimana fungsi yang ditentukan.

2) Menjaga/meningkatkan umur mesin

3) Mengurangi perawatan/maintenance

Komponen sistem ventilasi kamar mesin:

1) intake fan /fan untuk memasukkan udara ke kamar mesin
2) exhaust fan untuk menarik udara didalam supaya keluar ketika temperatur udara di kamar mesin meningkat.

3) Mist eliminator untuk mengekstrak uap/kabut dan air laut dari intake fan.

Sistem ventilasi kamar mesin seharusnya telah direncanakan dan diperhitungkan dari awal sebelum mesin dan permesinan lainnya dipasang. Petunjuk/manual tentang sistem dan perhitungannya juga harus tersedia.intake/saluran udara masuk harus secara langsung diarahkan ke dasar/bottom ruangan dan sebaliknya exaust diletakkan di tempat tertinggi dari ruang untuk sirkulasi dan perpindahan panas konveksi secara natural yang sempurna.

Jumlah kebutuhan udara berbeda-beda antara satu kondisi, permesinan dll. Sehingga kapasitas udara harus lebih besar dari kebutuhan/perhitungan. Metode perhitungan dapat mengacu pada standart ISO 8861berkaitan dengan "Engine room ventilation in diesel engined ship", metode dari ASHRAE dan metode lain seperti Desain Manual for General Arrangement of Engine Room.

Analisa perhitungan dengan metode ISO dan ASHRAE telah digunakan pada penelitian sebelumnya pada kapal tipe sama 2000GT tetapi di bangun di galangan berbeda sehingga komponen blower dan jumlah yang digunakan juga berbeda dengan kapal yang digunakan pada studi kasus pada artikel ini.

Menurut standart ASHRAE perhitungan kebutuhan udara ventilasi didasarkan pada beberapa beban panas (heating load):

1) Beban panas transmisi, karena perbedaan temperatur dalam dan luar ruang.

2) Beban panas penghuni, kalor yang dikeluarkan setiap orang dalam ruangan

3) Beban panas akibat rambatan dari kaca cendela

4) Beban panas dari lampu penerangan. 
5) Beban panas dari peralatan di ruang mesin (main engine, Auxiliary Engine, motor listrik dan permesinan lainnya)

Menurut ISO 8861, perhitungan kapasitas udara total di dasarkan pada:

1) Kapasitas udara untuk pembakaran main engine, auxiliary engine dan boiler.

2) Kapasitas udara untuk panas emisi dari main engine dan permesinan lainnya.

Dengan metode "Desain Manual for General Arrangement of Engine Room" yang digunakan oleh program studi teknik sistem perkapalan ITS Surabaya, perencanaan/perhitungan sistem udara ventilasi untuk kamar mesin harus dipertimbangkan beberapa hal sesuai fungsinya sebagai :

1) Penyedia kebutuhan udara pembakaran untuk main engine, generator set, boiler.

2) Menyebarkan/membaurkan panas yg dipancarkan dari permesinan, boiler, motor, dan penukar kalor

3) Penyedia udara segar untuk menjaga keadaan tetap sehat.

Kebutuhan udara untuk pembakaran motor diesel sebagai berikut (1).

$$
\mathrm{Q}=\frac{F \times v \times m \times H}{60}
$$

Dimana :

Q: kebutuhan udara pembakaran $\left(\mathrm{m}^{3} /\right.$ $\min$ )

F: Konsumsi bahan bakar saat putaran maksimum/ MCR (kg/PS. hr)

$\mathrm{m}$ : Excessive air ratio(rasio kelebihan udara) 3-3,6 untuk diesel dua langkah (2stroke) ukuran besar

\section{1,5- 2 untuk diesel 4langkah} (4stroke)

$\mathrm{H}$ : maksimum continuous output diesel (PS)
$\mathrm{V}$ : jumlah udara untuk membakar $1 \mathrm{~kg}$ bahan bakar $(\sim 12,1 \mathrm{~m} 3 / \mathrm{kg})$

Kebutuhan udara untuk Menyebarkan/membaurkan panas (heat diffusing) yg dipancarkan dari permesinan, boiler, motor, dan penukar kalor (2):

$$
\begin{aligned}
& \mathrm{Q}=\frac{H}{60 . \rho \cdot C p \cdot t} \ldots . \\
& \mathrm{H}=632,5 \text { P.f. }
\end{aligned}
$$

Dimana:

Q : Jumlah udara untuk menyebarkan radiasi panas $\left(\mathrm{m}^{3} / \mathrm{min}\right)$

$\mathrm{H}$ : Panas yg ingin dihilangkan (dissipated heat (kcal/hr))

P : Max Continuous output (daya maximum)

$\rho$ : Density udara kering $1.165 \mathrm{~kg} / \mathrm{m}^{3}$ pada temperatur $30^{\circ} \mathrm{C}$

Cp : Panas spesifik pada tekanan konstan udara kering $0,24 \mathrm{kcal} / \mathrm{kg}$ pada temperatur $30^{\circ} \mathrm{C}$

$\mathrm{t}$ : naiknya temperatur yang diijinkan didalam engine room

- untuk engine room $5,6-8,4{ }^{0} \mathrm{C}$

- untuk boiler room $11,1-13,7^{0} \mathrm{C}$

$\mathrm{F}_{1}$ : Diffusion rate

0.005-0.02 untuk main engine

0.015-0.02 untuk diesel main engine

0.025-0.03 untuk generator diesel eng

\section{METODE}

Metode yang digunakan dalam penulisan artikel ini adalah dengan mengumpulkan data primer berupada data-data dari galangan kapal, interview dengan teknisi/perencana di galangan kapal, mengumpulkan data-data dari buku, internet dll, data sekunder dibuthkan unutk melengkapi data primer yang kurang lengkap dan sebagai data pembanding. 
Langkah selanjutnya, adalah mencari metode-metode yang dapat digunakan untuk menyelesaikan masalah yang ada. Dalam hal ini mencari metode - metode yang sudah dilaksanakan dalam jurnal/penelitian. Setelah mengetahui metode yang digunakan penulis coba menggunakan metode lain untuk memecahkan masalah sehingga hasil akhir didapat beberapa data, dari data tersebut dilakukan analisa dan penggambilan kesimpulan.

\section{HASIL DAN PEMBAHASAN}

Kapal perintis 2000DWT memiliki 2 buah mesin induk (Main Engine) type 12 AYMWST YANMAR dengan spesifikasi sebagai berikut:

$\begin{array}{ll}\text { Jml Silinder } & : 12 \\ \text { Daya (Power Output) } & : 1400 \mathrm{HP}(1030 \mathrm{~kW}) \\ \text { Putaran } & : 1900 \mathrm{rpm} \\ \text { SFOC } & : 0,156 \mathrm{~kg} / \mathrm{HP} . \mathrm{hr} \\ \text { Caloric value of oil } & : 10.206 \mathrm{kcal} / \mathrm{kg}\end{array}$

Sedangkan untuk pembangkit listrik menggunakan 3 generator set (Auxiliary Engine) dan 1 generator pelabuhan:

Merek Bauduoin type 6M19.3

$\begin{array}{ll}\text { Jml Silinder } & : 6 \\ \text { Daya (Output) } & : 339 \mathrm{KW} \\ \text { Putaran } & : 1500 \mathrm{rpm} \\ \text { SFOC } & : 0.198 \mathrm{~kg} / \mathrm{kW} . \mathrm{hr} \\ \text { Caloric value of oil } & : 10.206 \mathrm{kcal} / \mathrm{kg}\end{array}$

Spesifikasi blower untuk main engine berbeda dan terpisah dengan yang digunakan untuk auxiliry enginel genset dikarenakan ruang mesin terpisah oleh sekat/dinding.

Spesifikasi blower untuk main engine setelah mengalami penggantian rpm:

$\begin{array}{ll}\text { Merek } & : \text { Regal marine Axial Fan } \\ \text { Type } & : \text { RP-36 } \\ \text { Power } & : \text { 4Kw }(5,5 \mathrm{HP}) \\ \text { Putaran } & : \text { 960 rpm } \\ \text { Model } & : \text { Axial mushroom } \\ \text { Jumlah } & : \text { 2buah (kanan-kiri) }\end{array}$

Spesifikasi blower untuk auxiliary engine:

$$
\begin{array}{ll}
\text { Merek } & \text { : DS.Group } \\
\text { Type } & : \text { BLR-24MRN } \\
\text { Power } & : 3 \mathrm{HP} \\
\text { Putaran } & : 1400 \mathrm{rpm} \\
\text { Model } & : \text { Axial mushroom } \\
\text { Jumlah } & : 2 \text { buah (kanan-kiri) }
\end{array}
$$

Dalam layoutkamar mesin kapal perintis 2000GT (gambar2), dapat diketahui 2 buah mesin induk (M/E), 3 diesel generator set (A/E) dan 1 genset emergency yang diletakkan dalam ruang terpisah. Oleh karena itu dalam perhitungan kebutuhan udara ventilsi juga terpisah.

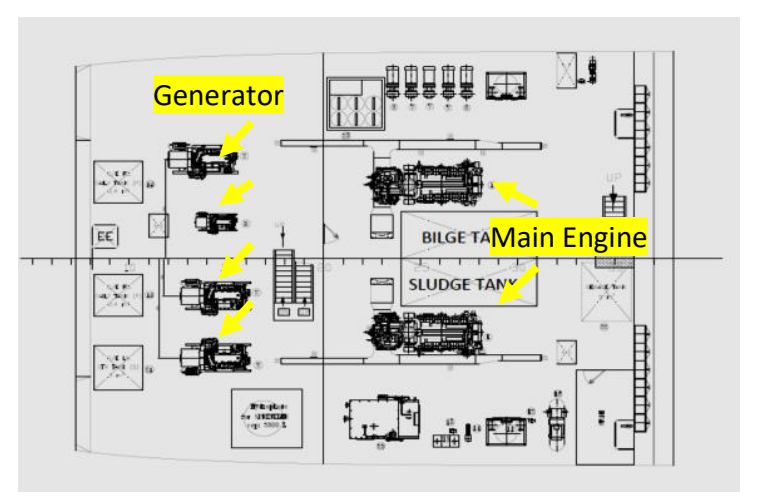

Gambar 2. Lay out Kamar Mesin ruang sebelah kiri 3 generator, sebelah kanan 2 main engine

Dalam kasus ini, perhitungan dilakukan karena adanya pergantian motor penggerak axial fan untuk main engine hingga $2 \mathrm{kali}$, dari spesifikasi awal (tidak didapat data), penggantian pertama dengan RPM lebih dari 1000rpm, kemudian karena bising dan dikawatirkan akan merusak peralatan maka penggantian ke dua dilakukan dengan RPM 960 yang hingga saat ini digunakan.

Pada perhitungan kapal sejenis pada penelitian yang sudah dilakukan hanya menggunakan blower 1 buah dengan kapasitas yang besar $40000 \mathrm{cfm}$ untuk mensuplai ruang $\mathrm{M} / \mathrm{E}$ dan $\mathrm{A} / \mathrm{E}$, sedang pada artikel ini ruang terpisah dengan menggunakan blower terpisah pula. 
Dengan metode Desain Manual for General Arrangement of Engine Room, Hasil perhitungan kebutuhan udara untuk pembakaran untuk 1 main engine dapat dilihat pada gambar 3:

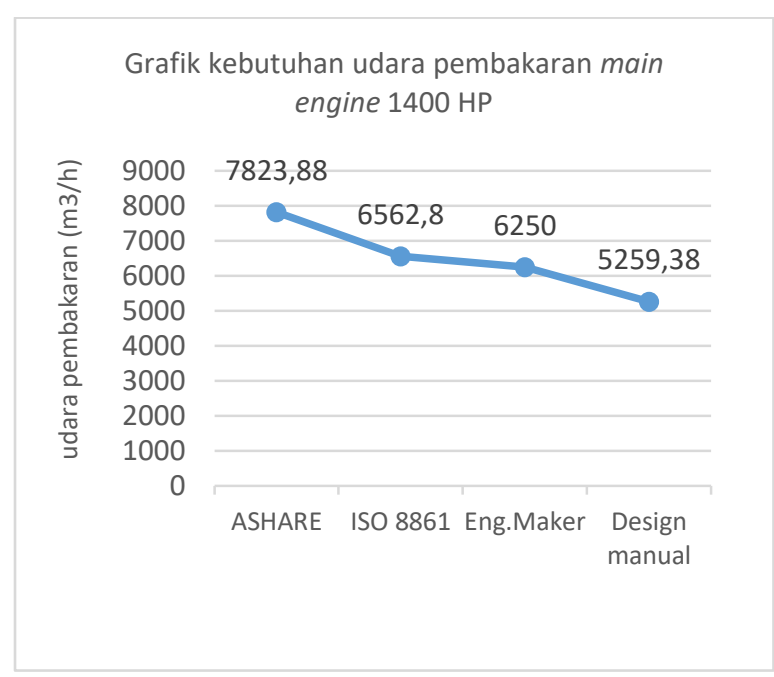

Gambar 3. Kebutuhan udara pembakaran untuk main engine dengan 4 metode berbeda.

Dari 4 metode tersebut dapat diketahui perhitungan dengan menggunakan desain manual memiliki angka terkecil bahkan lebih kecil dari yang disebutkan di buku manual dari pembuat mesin diesel.

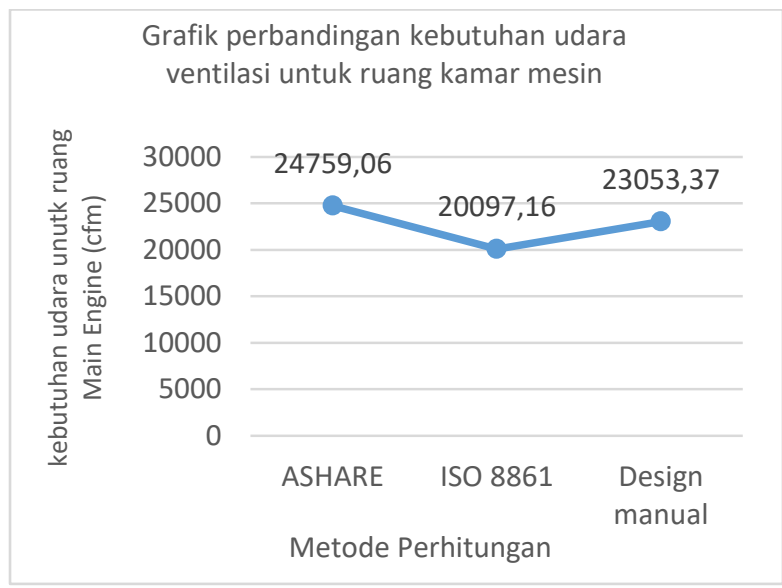

Gambar 4. Total kebutuhan udara untuk ruang $\mathrm{M} / \mathrm{E}$

Dari gambar 4, dapat diketahui jumlah udara ventilasi yang harus disediakan untuk udara pembakaran dan difusi udara panas akibat radiasi dari $\mathrm{M} / \mathrm{E}$, dengan metode desain manual memiliki nilai 23.053,37 cfm, lebih tinggi dari persyaratan ISO $886120097.16 \mathrm{cfm}$, namun masih lebih rendah dari hasil ASHARE yaitu 24.759,06. sehingga jika menggunakan metode design manual masih memenuhi syarat karena kebutuhan udara unutk emisi masih lebih tinggi dari ISO 8861 yang sehingga bisa menutupi kekurangan untuk udara pembakaran yang di persyaratkan maker.

Dikarenakan data awal yang kurang lengkap, untuk mencari kapasitsas axial fan digunakan pembanding dengan daya dan putaran yang hampir sama, diameter fan yang sama. Sehingga dapat diketahui kapasitas blower terpasang masing-masing memiliki kapasitas $15000 \mathrm{cfm}$. Dengan 2 buah fan didapat total sebesar $30000 \mathrm{cfm}$. Jika didasarkan dari gambar 4, maka bisa disimpulkan sudah mencukupi untuk memenuhi karena menurut perhitungan kebutuhan hanya sekitar $20.000 \sim 24$. dengan asumsi sisa udara unutk pembakaran dan difusi panas digunakan untuk mengatasi beban panas dari komponen listrik, crew dll.

\section{KESIMPULAN}

Dari hasil pembahasan perhitungan kebutuhan udara ventilasi pada engine room kapal perintis 2000GT di galangan kapal semarang dengan adanya penggantian motor fan blower dapat diambil kesimpulan sebagai berikut:

1) Metode perhitunggan kebutuhan udara ventilasi dapat menggunakan berbagai metode, dan hasilnya pun tidak begitu jauh berbeda, namun jika di terapkan di kapal, harus mendapatkan approval dari biro klasifikasi

2) Metode Desain Manual for General Arrangement of Engine Roomdapat digunakan untuk menghitung kebutuhan udara ventilasi di engine room karena memiliki nilai antara ASHARE dan ISO 8861.

3) Blower dengan rpm 960 dan diameter fan 36" di kamar mesin memiliki 
kapasitas 2 x 15000cfm cukup untuk udara pembakaran dua main engine dan difusi panas dari M/E yaitu sebesar $23053,37 \mathrm{cfm}$

4) Untuk metode perhitungan dengan "Desain Manual for General Arrangement of Engine Room" hanya dijelaskan formula untuk menghitung udara pembakaran dan difusi panas, sedang unutk standar kesehatan dapat mengacu pada standart yang berlaku, dan hanya disebutkan harus memenuhi paling tidak terjadi sirkulasi $20 \mathrm{x}$ tiap jamnya.

5) Untuk exaust fan harus disediakan jika rule/klasifiksi mempersyaratkan.

6) Saluran udara (duck) harus direncanakan sehingga kecepatan aliran udara berkisar 12-13 $\mathrm{m} /$ detik, dan di percabangan berkisar $10 \mathrm{~m} /$ detik.

7) Dalam perencanaan hendaknya dugunakan beberapa metode dan kapal lain sejenis sebagai data pembanding.

\section{DAFTAR PUSTAKA}

Biro Klasifikasi Indonesia,2006, Machinery Instalation, Vol III, chapter I (Rule /Standart Klass)

Husnul Khotimah, 2017,Perencanaan Sistem Ventilasi dan Pengaturan Udara Pada Kamar Mesin Kapal,PPNS Surabaya, (Studi Kasus Pada Kapal Perintis 2000GT di PT Orela Shipyard),

ISO 8861. Shipbuilding-Engine Room Ventilation in Diesel engined ShipsDesign Requirement and basic of calculation.(International Standard International Standard )

independensi , 2018, Presiden-jokowiresmikan-11-kapal-pendukungtollauthttps:/independensi.com/

(Situs Internet)

Kapal-perintis-sabuk-nusantara-88-

diluncurkan,2017

https:/ekonomi.bisnis.com/read/

(Situs Internet)
Marine dieseleurope, 2014, engine-roomventilation www.Marinedieseleurope.com/blog/2014/ 01/01/ (Situs Internet) 